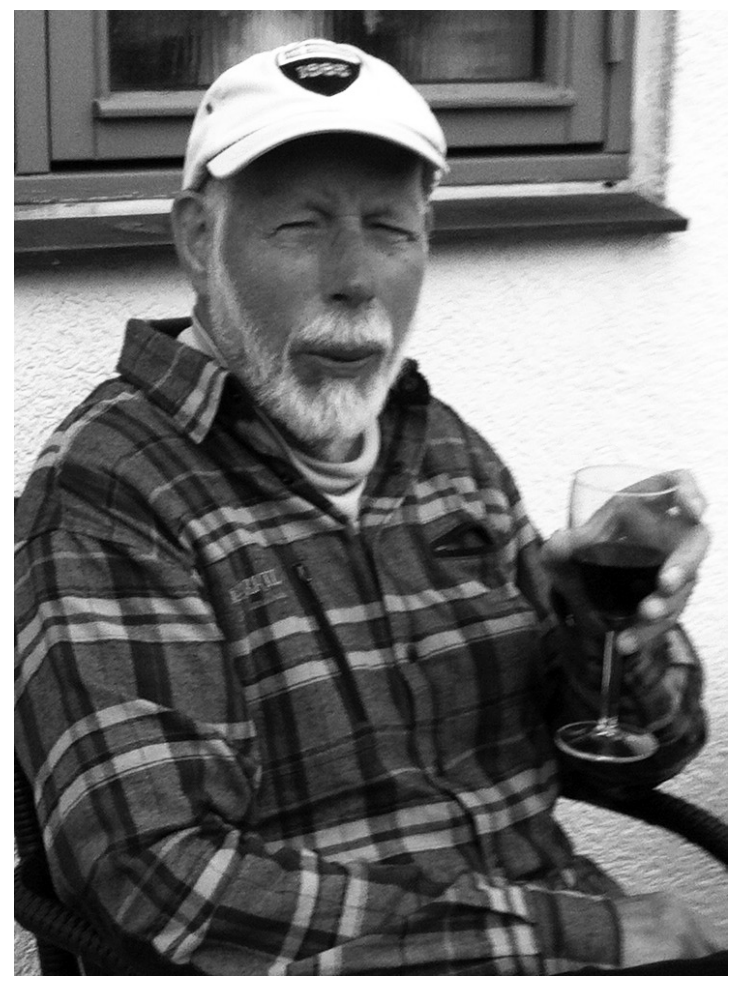

Privatfoto

$$
\text { Jørgen Elbeck }
$$

8. december 1934 - 31. maj 2014 


\title{
Jørgen Elbek in memoriam
}

\author{
Kim Arne Pedersen
}

I en kort og præcis nekrolog over en ældre kollega skrev Jørgen Elbek i 2001, at heller ikke denne "kunne bryde den lukkethed om sig selv, der har været Grundtvigforskningens forbandelse”. På en vis måde var det Jørgen Elbeks intention med sin Grundtvigforskning netop at ville bryde ud. Det gjorde han ved at vise, at forfatterskabet med Grundtvigs egne ord var "et vel maadelig corrigeret men derfor just des troere Aftryk" (US VI, 11) af det liv, han havde levet. Elbek forstod livet som en erkendelses- og dannelsesproces, og han mente, man kunne lære af Grundtvigs tekster, fordi de var tæt forbundet med Grundtvigs egen personligheds fuldbyrdelse. Forfatterskabet skulle læses, fordi det var vedkommende for det menneske, der er på vej mod sig selv.

Det afgørende for Elbek var, at læser og digter er fælles om en række "erfaringsmuligheder", som han skriver i sit grundlæggende essay, "Kritikkens genmæle" i første nummer af tidsskriftet Kritik i 1967. Elbek kontrasterer i dette essay en formalistisk tradition med sin egen eksistentialistiske modtradition, hvor hovednavnene er Vilhelm Andersen, Ejnar Thomsen og Aage Henriksen, og bag dem Goethe og forskellige repræsentanter for den tyske idealisme. Jørgen Elbeks biografisk-eksistentialistiske tilgang til Grundtvigs forfatterskab havde den konsekvens, at han forholdt sig kritisk til grundtvigianerne, hos hvem, han mente, at Grundtvigs tanker blev til ideologi. Dette opgør var til dels personligt: De grundtvigske miljøer kendte han fra sin egen slægt. Hans farfar, Johannes Elbek, drev højskole i landsbyen Elbek syd for Odder. Faderen Helge Elbek blev teolog og først sognepræst i Øster Tørslev (hvor Elbek kom til verden), siden valgmenighedspræst i Vrå, hvor Elbek, fra han var halvandet år, trådte sine barnesko 
frem til optagelsen på Rungsted Statsskole som 15-årig. I 1956 giftede han sig med studiefællen Alice Beckmann, og i 1961 afsluttede han sin embedseksamen i dansk og græsk kultur ved Københavns Universitet. Derefter var han først amanuensis, siden lektor i nordisk litteratur ved Aarhus Universitet indtil pensioneringen i 1998.

Elbeks Grundtvigforskning påbegyndtes allerede i studietiden med den epokegørende specialeafhandling, Grundtvig og de greske salmer, der i 1960 udkom i bogform på Gads Forlag, året efter at han i en artikel havde behandlet Grundtvigs gendigtninger af latinske salmer i Grundtvig-Studier. Elbek havde travlt under færdiggørelsen af specialeafhandlingen. Han havde stiftet familie, og det gjaldt om at få studiet afsluttet. Alligevel gjorde han i dette første arbejde nogle helt nye opdagelser. F.eks. identificerede han Grundtvigs kilde til gendigtningerne af hymner fra den ortodokse tradition, en sent udgivet liturgisk håndbog for græsk-ortodokse præster. Elbek læste uden vanskeligheder græsk og latin, og i de blændende analyser af de enkelte salmer demonstrerede han desuden et omfattende kendskab til den ortodokse teologi og liturgi. Blandt Grundtvigforskere har man mere end én gang hørt bemærkningen: "Ja, den skulle han have haft doktorgraden for."

Jørgen Elbek selv fik dog hurtigt et noget distanceret forhold til denne sin første udgivelse. Det hang sammen med mødet med den forsker, der ved siden af Ejnar Thomsen fik varigst betydning for ham. Allerede 10 år før rækken af københavnske Aage Henriksen-elever dannede skole, blev Elbeks retning som litteraturfortolker således afgørende bestemt af kontakten med ham. Elbek har i en af sine sene erindringsskitser, "En vej til ord", fra 2010 skildret det skelsættende møde med Aage Henriksen, der ændrede hans holdning til fortolkningskunsten og førte til, at Sven Møller Kristensen brugte betegnelsen "litteraturteologer" om ham og hans ligesindede.

Indflydelsen fra Aage Henriksen betød endvidere, at de mange essays om Grundtvig, som siden kom fra Elbeks hånd, stod at læse side om side med analysen af andre forfatterskaber, og at han i bøgerne Grundtvigs atten prøveår fra 1973 og Grundtvig og syvstjernen fra 1981 inddrog digtere, man ikke mødte i andre Grundtvigforskeres behandling af samme emner. Elbek spændte umådelig vidt: Platon, Goethe, Sophus Claussen, Jakob Knudsen og Johannes V. Jensen med flere. Hans bog om sidstnævnte førte til heftige angreb ved udgivelsen i 1966, da den blev opfattet som 
et overfald på et af de nationale koryfæer. Sådan var den imidlertid ikke ment. Den var Elbeks livtag med et stort forfatterskab og den kurs, det tog efter ungdomsårene ud fra den karakteristiske eksistentialistiske tilgang til forskningen, som han hyldede, og bogen gav Johannes V. Jensenforskningen en ny retning.

Også som universitetslærer var det Elbeks anliggende at gøre litteraturen eksistentielt vedkommende for sine elever. Det skete uden at give køb på det faglige håndværk, der også hører med til analysen. Han var vellidt og beundret, men også frygtet for sine høje krav. Højest var dog utvivlsomt de krav, han stillede til sig selv. Elbek fastholdt tværs gennem universitetsmarxismens æra sin eksistentialistiske tilgang til litteraturfortolkning og tilførte derigennem sit fag et element af tradition og dannelse, der savnedes i disse år. Selv var han i sin livsførelse og sine holdninger ikke uberørt af nybruddet i 1960'ernes anden halvdel, og som samfundsborger var han ikke blot en forkæmper for menneskets omgivende natur i ord. Han og hustruen levede vegetarisk og dyrkede selv deres grønsager - usædvanligt for travle akademikere, men et eksempel på den sammenhæng mellem liv og engagement, som prægede Jørgen Elbek. For nogle af os yngre forskere var besøgene i huset ved Dyngby Strand en sand oplevelse, hvor natur, husets billedkunst og ægteparrets viden og indsigt gik op i en højere enhed. 